Dlouhy J., Binninger M., Weichner L. and Haghsheno S. (2017). "Implementation of Lean Construction in Client Organizations- an Analysis of the Status Quo in Germany.” In: LC3 2017 Volume II - Proceedings of the 25th Annual Conference of the International Group for Lean Construction (IGLC), Walsh, K., Sacks, R., Brilakis, I. (eds.), Heraklion, Greece, pp. 275-282. DOI: https://doi.org/10.24928/2017/0089

\title{
IMPLEMENTATION OF LEAN CONSTRUCTION IN CLIENT ORGANIZATIONS - AN ANALYSIS OF THE STATUS QUO IN GERMANY
}

\author{
Janosch Dlouhy $^{1}$, Marco Binninger ${ }^{2}$, Lisa Weichner ${ }^{3}$, and Shervin Haghsheno ${ }^{4}$
}

\begin{abstract}
Lean Construction is a management approach that is not only relevant for construction companies but also for their clients. The goal of this paper is to present the current status of strategies for implementation of Lean Construction within client-side organizations in Germany. A significant foundation principle in Lean Construction is the definition of value from the perspective of the client. Value is predominantly defined through the design and functional quality of a building as well as keeping to the defined time and cost objectives. In construction, the developer as a client has several tasks to fulfil which have a significant impact on the success of a project. Some developers seek to actively contribute to defining and managing meeting of their own client wishes. This requires using the approach and tools of Lean Construction, and these efforts have resulted in implementation strategies. Analysis of the status of implementation within client-side organizations was completed through interviews with eight companies in Germany. This paper will explain the method of data collection, the structure of the organizations surveyed. The implementation strategies will be described for each organization and classified according to the applicable framework conditions. The results determined that the companies use various approaches which are at different stages of implementation. This paper thereby provides a preliminary empirical overview of the situation regarding implementation of Lean Construction by development companies in Germany, and can be used by other developers as a basis for their first steps in implementing Lean Construction.
\end{abstract}

Keywords: Lean construction, computing, mixed reality, template, instructions.

\section{INTRODUCTION}

Womack begins his book 'Lean Thinking' by stating "The critical starting point for lean thinking is value. Value can only be defined by the ultimate customer" (Womack and Jones 2003). When applying this to lean in the construction industry, two questions are posed: Who is the end client in this construction process, and how does this client define the value of a construction project? This paper will not offer a definite answer to these questions, but rather practical observations and analysis as a basis for further research into value to the ultimate costumer. The client of a building project is not always the end client, but these roles could be combined that could be confusing. To clarify understanding of

\footnotetext{
1 Research Fellow, Karlsruhe Institute of Technology, Germany, +49-721-608-42168, janosch.dlouhy@kit.edu

2 Research Fellow, Karlsruhe Institute of Technology, Germany, +49-721-608-44124, marco.binninger@kit.edu

M.Sc. Student, Karlsruhe Institute of Technology, Germany, +49-721-608-43650, lisaweichner@gmail.com

4 Professor, Karlsruhe Institute of Technology, Germany, +49-721-608-42646, shervin.haghsheno@kit.edu
} 
these roles, a client who is both the end client and user will be described in this paper as the "ultimate client" according to Womack and Jones (2003). The ultimate client presents a clear difference to the role of "ultimate customer". The ultimate customer generally has no influence over the production process for creating value. The production company has sole responsibility for the conditions of production. Conversely the ultimate client in the construction process has final responsibility and sets the framework conditions for the production company. According to German architect Otto Bartning (Gautier 2014), 50\% of all services are to be provided by the client. Therefore, clients are responsible for important tasks and functional areas during execution of construction projects. To better understand the ultimate client and his or her perception of value, this research analyzed the lean activates of known ultimate clients in Germany. The authors have limited the sample to industrial clients as in contrast to public-sector or private clients, these fill the role of client as well as the user and operator (Bertelsen and Emmitt 2005). Selection of industrial clients means that the company is building to satisfy its own demand and selects the location as well as volume of investment according to the goals of their main area of business (Glatte 2012). These goals include short design and build times for production buildings, as well as to guarantee sufficient production and secure their market segment (Girmscheid 2010). The resultant requirements have led to various approaches for lean construction implementation being developed within German client-side organizations.

The goal of this paper is to document efforts toward lean construction from the perspective of the ultimate client. Additionally, the different forms of this are identified and assessed according to lean construction principles. This allows the current status of lean construction implementation by industrial concerns acting as construction clients in Germany to be determined.

\section{RESEARCH METHOD}

Due to a lack of literature on the topic of clients and how they carry out projects, it is not possible to gather sufficient written factual data on this topic. In order to gain a perspective on client implementation concepts which is as realistic as possible, data was gathered qualitatively in the form of expert interviews. This was arranged as a partially standardized questionnaire to allow simplified access to complex knowledge from interviewees (Hohl 2000).

The interviews were carried out using open questions with the help of additional knowledge gathering strategies. These strategies are characterized by the use of varying types of questions (Scheele and Groeben 1988). The questionnaire encompassed open, closed and hybrid questions (Kruse 2014). The combination of these types of questions created the possibility of gaining an overview of the lean methods used, and at the same time offered the potential for discovering new methods. Lean terminology was not used in order to prevent potential confusion that maybe caused by jargon. In total there were 23 questions of which eight were open questions and 15 were closed questions. Of the 15 closed questions, four were hybrid questions. The goal was to gain additional background information on how projects are executed. In addition to questions on the use of lean methods, the questionnaire also included general questions regarding the types of buildings, volume of construction and the organizational structure of the building department of the applicable company. Additionally, there were questions on project organization, project execution, project control and measures applied in cases where there were deviations from the project goals. The recorded data was anonymized to protect the identity of the participants. The selection of interviewees was completed through a 
combination of gatekeepers and internet research to simplify access to interviewees (Kruse 2014). The organizations invited should be active in the industrial sector and have an inhouse construction department. Ideally they should have knowledge of, or even have implemented lean construction methods. The interviewees held a management position in the construction department, or were directly involved with the lean implementation process. As the questionnaire included open and hybrid questions, data was assessed through coding of the questions. Thereby similar answers could be categorized. After categorization was completed, the hybrid questions could be assessed in the same way as the closed questions. It is important to include a category such as "no answer". The approach of interpreting the answers was completed using Flick's method of thematic coding which comprises three steps (Flick 1995).

1. Case by case analysis: This includes a short description of each case and results with respect to the question asked and the central themes of this research (Reuber and Pfaffenbach 2005).

2. In-depth analysis: A specific account related to the topic of this research is presented. Relevant connections between individual answers are sought. The goal is to develop a system of categorizations for each individual case which can be applied to the interviews that follow, and be modified as needed. (Flick 1995)

3. Typification: The final step includes the finding similarities and differences between different cases and categories. Types can be developed to subsume the specific cases. The construction of types occurs through summarizing the specific cases according to specific characteristics. The specific cases of one type only have small differences (internal homogeneity). The characterization of individual types is thereby as strong as possible (external homogeneity). (Flick 1995)

\section{STATUS QUO IN GERMANY}

Evaluation of the gathered data shows that as a result of client demands, more efficient supply systems, simplified standards, quality improvements, cost optimizations and transparency of various lean management concepts have been developed. There are similarities with regard to the influencing factors for project execution and types of buildings.

\subsubsection{Company 1}

An Industrial company with more than 150 million $€$ annual construction volume. 
Table 1: Elements and Effects of lean construction implementation

\begin{tabular}{cc}
\hline Elements & Effects \\
\hline $\begin{array}{c}\text { Preliminary draft for basis for standardized } \\
\text { construction types with fixed construction and } \\
\text { execution standards }\end{array}$ & $\begin{array}{c}\text { Reduction of project duration by } 20 \% \\
\text { through shortening of time needed for } \\
\text { design and determining requirements } \\
\text { Cost tools }\end{array}$ \\
$\begin{array}{c}\text { Reduction in investor costs by up to } 15 \% \\
\text { and operational costs by u to } 5 \%\end{array}$ \\
Economies due to serial production & \\
Contractual relationship with preferred & \\
suppliers & \\
\hline
\end{tabular}

\subsubsection{Company 2}

An Industrial company with more than 150 million $€$ annual construction volume.

Table 2: Elements and Effects of lean construction implementation

\begin{tabular}{cc}
\hline Elements & Effects \\
\hline Design phase: Planning of design, & Shortening of project duration \\
modularization (incl. BIM) and Target Value & Stabilization of quality \\
Design. Planning of design is based on Takt & Achieving of transparency \\
Planning & \\
Execution phase: Takt Planning of the & \\
construction sequence, Takt management and \\
logistics concepts
\end{tabular}

\subsubsection{Company 3}

Industrial company with 50 - 100 million $€$ annual construction volume

Table 3: Elements and Effects of lean construction implementation

\begin{tabular}{cc}
\hline Elements & Effects \\
\hline Preparation of a standard construction & Shortening of project duration \\
catalogue & Problems with quality and fire protection \\
pocumentation organized across multiple & \\
Restructuring of the internal client organization \\
Modular construction
\end{tabular}

\subsubsection{Company 4}

Trading corporation with 50 - 100 million $€$ annual construction volume 
Table 4: Elements and Effects of lean construction implementation

\begin{tabular}{cc}
\hline Elements & Effects \\
\hline $\begin{array}{c}\text { Fixed definition of construction and execution } \\
\text { standards }\end{array}$ & Shortening of project duration \\
Lean awarding of contracts through long-term & \\
framework contracts based on a specification of \\
services which describes all necessary works \\
and materials to be used \\
Cooperative project execution processes \\
achieved through long-term business \\
relationships \\
Increased efficiency through repetition
\end{tabular}

\subsubsection{Company 5}

Industrial company with less than 50 million $€$ annual construction volume

Table 5: Elements and Effects of lean construction implementation

\begin{tabular}{cc}
\hline Elements & Effects \\
\hline $\begin{array}{c}\text { Consistent process systems to increase } \\
\text { efficiency in the construction sequence made } \\
\text { up of an overall process analysis, process } \\
\text { planning and steering of the performance } \\
\text { Embedding a Bonus/Malus system into } \\
\text { contracts with design consultants }\end{array}$ & $\begin{array}{c}\text { Development of a professional and } \\
\text { structured execution of construction that } \\
\text { keeps within cost and timeline } \\
\text { constraints }\end{array}$ \\
$\begin{array}{c}\text { Project organizations with integrated user } \\
\text { management }\end{array}$ & $\begin{array}{c}\text { Transparency for clients and all parties } \\
\text { involved with the project }\end{array}$ \\
& $\begin{array}{c}\text { Intensine involvement of users leading to } \\
\text { minimization of variations }\end{array}$ \\
& $\begin{array}{c}\text { Partnerships and trusting collaboration } \\
\text { instilled in all project participants }\end{array}$ \\
\hline
\end{tabular}

\subsubsection{Company 6}

Industrial company with less than 50 million $€$ annual construction volume 
Table 6: Elements and Effects of lean construction implementation

\begin{tabular}{cc}
\hline Elements & Effects \\
\hline $\begin{array}{c}\text { Consistent process systems to increase } \\
\text { efficiency in the construction sequence made } \\
\text { up of an overall process analysis, process } \\
\text { planning and steering of the performance }\end{array}$ & $\begin{array}{c}\text { Early identification and sustainable } \\
\text { management of disruptions }\end{array}$ \\
Structuring of work packages during the design \\
phase using an activity board
\end{tabular}

\subsubsection{Company 7}

Industrial company with less than 50 million $€$ annual construction volume

Table 7: Elements and Effects of lean construction implementation

\begin{tabular}{cc}
\hline Elements & Effects \\
\hline Takt Planning and Takt Control \\
Logistics concepts & $\begin{array}{c}\text { Reduction of project duration, costs and } \\
\text { product limitations }\end{array}$ \\
\hline
\end{tabular}

\subsubsection{Company 8}

Trading corporation, annual construction values not disclosed

Table 8: Elements and Effects of lean construction implementation

\begin{tabular}{cc}
\hline Elements & Effects \\
\hline $\begin{array}{c}\text { Fixed definition of construction and execution } \\
\text { standards across all of Germany }\end{array}$ & $\begin{array}{c}\text { Competitive and stable prices } \\
\text { Standardization of execution of works } \\
\text { and reduced problems with interfaces } \\
\text { between trades as works and execution } \\
\text { standardized tender specification } \\
\text { standards are known }\end{array}$ \\
$\begin{array}{c}\text { Framework contracts with general contractors } \\
\text { Pre-prepared planning of works regarding } \\
\text { division of labor and internal fit-out }\end{array}$ & \\
\hline
\end{tabular}

\section{FINDINGS}

The evaluation is based on the analysis of similarities and differences related to execution concepts, influencing factors, focus and effects on course of a project as well as comparing them to the scientific basis.

Categories are defined based on the company's assessment of tools and methods used. This evolved two significant strategies: the product strategy and the process strategy. The basis for this categorization is the definition of the characteristics of standardized processes and products according to Aapojla (et al. 2014). The product strategy creates consistent building and fit-out standards which can be adjusted to site specific conditions. Conversely the companies found to be using process strategies applied tools and methods such as Takt Planning and Takt Control and adaptations of the Last Planner ${ }^{\mathrm{TM}}$ System. 
These should generate transparency, predictability and stability to the construction process.

Furthermore, effects can be seen in the execution strategy for project organization, project sequence, project control and for managing changing project expectations. Comparison with the available literature, Glatte (2014) confirms that corporate strategies have significant effects on the real estate strategy and thereby influence the selection of project execution strategy.

Figure 1 shows how the real estate strategy influences the execution strategy of ultimate clients. For the product strategy, the ultimate client is characterized by corporate design, which determines the structure and equipment used. The process strategy fulfils the requirements of ultimate clients who have various kinds of buildings with a unique character. It must be ensured that both strategies remain focused on completion of the building within the given timeline to keep to the required opening date or start of production, and to best fulfil the applicable corporate strategy.

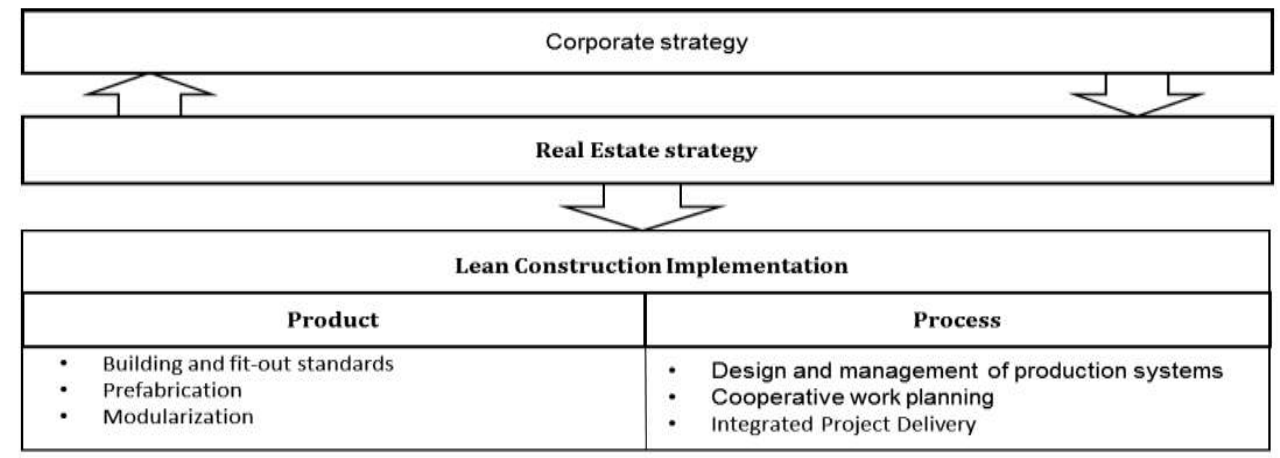

Figure 1: Influences on implementation strategies

Moreover, it is shown that currently only a small proportion of the available tools have been used. In particular, during the design phase lean methods are rarely used, as is shown in Table 9.

Table 9 Overview of the lean tools used

\begin{tabular}{|c|c|c|c|c|c|c|c|c|}
\hline \multirow[t]{2}{*}{ Elements } & \multicolumn{8}{|c|}{ Company } \\
\hline & 1 & 2 & 3 & 4 & 5 & 6 & 7 & 8 \\
\hline \multicolumn{9}{|l|}{ Last Planner System } \\
\hline \multicolumn{9}{|l|}{ Integrated Project Delivery } \\
\hline Takt Planning/ Takt Management & & $\mathrm{X}$ & & & $\mathrm{X}$ & $\mathrm{X}$ & $\mathrm{X}$ & \\
\hline Target Value Design & & $\mathrm{X}$ & & & & & & \\
\hline \multicolumn{9}{|l|}{ Agile Methods } \\
\hline \multicolumn{9}{|l|}{ Set Based Design } \\
\hline Modularization & $\mathrm{X}$ & $\mathrm{X}$ & $\mathrm{X}$ & & & & & \\
\hline \multicolumn{9}{|l|}{ Quality Function Development } \\
\hline Lean Construction Site logistics & & $\mathrm{X}$ & & & & & & \\
\hline
\end{tabular}


The current status of lean implementation for ultimate customers in Germany is shown in Figure 2 according to Schuh's Lean Maturity Model (Schuh 2013). "This maturity model describes how the effectiveness of lean innovation principles can be continually increased by changing structures and relationships. Working with ideal situations and the target outcomes derived thereof to serve in orienting all employees is especially important for continuous improvement." (Schuh 2013)

Only one company achieves maturity level of 'Lean Organised'. The others are categorized in the levels 'Ad Hoc' to 'Lean Initiated'.

\begin{tabular}{|c|c|c|c|c|c|c|c|c|}
\hline Maturity level & $\underset{1}{\text { Company }}$ & $\begin{array}{c}\text { Company } \\
2\end{array}$ & $\underset{3}{\text { Company }}$ & $\begin{array}{l}\text { Company } \\
4\end{array}$ & Company & Company & $\begin{array}{l}\text { Company } \\
7\end{array}$ & $\begin{array}{c}\text { Company } \\
8\end{array}$ \\
\hline \multicolumn{9}{|l|}{ Ad Hoc } \\
\hline Waste is not identified & & & $\mathrm{x}$ & $x$ & & & & \\
\hline Defining according to the customer is not known of & & & & $\mathrm{x}$ & & & & \\
\hline Lean Innovation principles are not known & & & $x$ & & & & & \\
\hline \multicolumn{9}{|l|}{ Lean Initiated } \\
\hline $\begin{array}{c}\text { Fundamental knowedge of Lean Innovation principles } \\
\text { exist }\end{array}$ & $\mathrm{x}$ & $x$ & & & $x$ & $x$ & $x$ & $\mathrm{x}$ \\
\hline Understanding of value and waste exist & $\mathrm{x}$ & $\mathrm{x}$ & $x$ & & $\mathrm{x}$ & $x$ & $x$ & $\mathrm{x}$ \\
\hline Transparent communication of guiding principles & $x$ & $x$ & & & & & & $x$ \\
\hline \multicolumn{9}{|l|}{ Lean Organised } \\
\hline Acceptance of Lean Innovation principles & $\mathrm{x}$ & $\mathrm{x}$ & & & $x$ & & & $x$ \\
\hline $\begin{array}{c}\text { Lean innovation implemented in methods and } \\
\text { processes }\end{array}$ & & $\mathrm{x}$ & & & & & & \\
\hline Improvement project occur regularly & & $x$ & & & & & & \\
\hline \multicolumn{9}{|l|}{ Lean managed } \\
\hline \multicolumn{9}{|l|}{ Application of Lean Innovation principles } \\
\hline \multicolumn{9}{|l|}{ The principles are basis for further improvements } \\
\hline \multicolumn{9}{|l|}{ A north star is formulated and communicated } \\
\hline \multicolumn{9}{|l|}{ Lean optimised } \\
\hline \multicolumn{9}{|l|}{ Evaluating amd Improving adherence to the principles } \\
\hline Continuous Improvements to reach the north star & & & & & & & & \\
\hline Lean Innovation is passed on the partners & & & & & & & & \\
\hline
\end{tabular}

Figure 1: Lean Maturity of the companies interviewed

\section{CONCLUSIONS}

This paper shows that the ultimate client develops various strategies to define value for the client, and how to achieve it. Thereby there is a clear internal definition of their own client value in this work. Achieving value to the client is not achieved just by selecting a method, but rather by choosing a product and process-driven strategy and aligning the regarding tools to them. The type of implementation is bound by strategic parameters, which is also linked to the client's area of business.

A recommendation to ultimate clients is that both strategies are taken into account for lean implementation across all project stages and across different projects using multiproject management. The current best practice is used by Company 2 which attempts to integrate the product into its process strategy.

\section{DISCUSSION}

The results of this paper have no general validity, but rather provide a sample investigation, as only a small number of interviewees were selected on a subjective basis. If other gatekeepers would have selected the companies, it is possible that the results would have been different.

It has been shown that ultimate clients exist, and this offers a basis for further research. 


\section{REFERENCES}

Aapaoja, Aki; Haapasalo, Harri (2014): The Challenges of Standardization of Products and Processes in Construction. Oslo (22nd Annual Conference of the International Group of Lean Construction).

Bertelsen, Sven; Emmitt, Stephen (2005): The Client as a Complex System. Sydney, Australia (13th Annual Conference of the International Group for Lean Construction;)

Flick, Uwe (1995): Handbuch qualitative Sozialforschung. Grundlagen, Konzepte, Methoden und Anwendungen. 2. Aufl. Weinheim: Beltz.

Gautier, Peter; Osebold, Rainard (2014): Die Wiederentdeckung des BauherrnBedarfsplanung als Grundlage für den weiteren Planungsprozess. Berlin: Deutsches Ingenieurblatt

Girmscheid, Gerhard (2010): Projektabwicklung in der Bauwirtschaft. Wege zur WinWin-Situation für Auftraggeber und Auftragnehmer. Berlin, Heidelberg: SpringerVerlag Berlin Heidelberg.

Glatte, Thomas (2014): Entwicklung betrieblicher Immobilien. Beschaffung und Verwertung von Immobilien im Corporate Real Estate Management. Wiesbaden: Springer Vieweg

Hohl, Joechim (2000): Das qualitative Interview. In: Journal of Public Health 8 (2), S. $142-$ 148. DOI: 10.1007/BF02962637.

J.Womack/D. Jones - Lean Thinking First Free Press Edition 2003 ISBN 0-7432-4927-5) S. 16.

Kruse, Jan (2014): Qualitative Interviewforschung. Ein integrativer Ansatz. Weinheim: Beltz Juventa (Grundlagentexte Methoden)

Reuber, Paul; Pfaffenbach, Carmella (2005): Methoden der empirischen Humangeographie. Beobachtung und Befragung. 1. Aufl. Braunschweig: Westermann (Das geographische Seminar).

Scheele, Brigitte; Groeben, Norbert (1988): Dialog-Konsens-Methoden zur Rekonstruktion subjektiver Theorien. Die Heidelberger Struktur-Lege-Technik $<$ SLT $>$, konsensuale Ziel-Mittel- Argumentation u. kommunikative Flußdiagramm-Beschreibung von Handlungen. Tübingen: Francke.

Schuh, Günther (2013): Lean Innovation. Berlin, Heidelberg: Imprint: Springer Vieweg. 